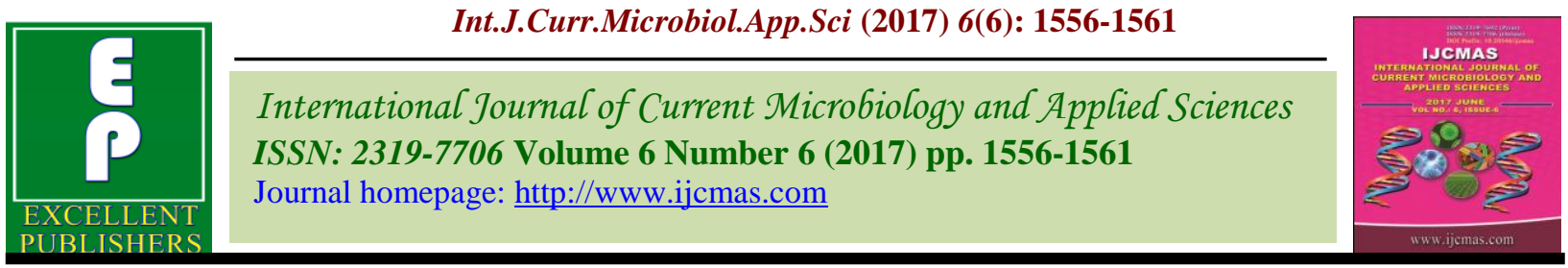

Original Research Article

https://doi.org/10.20546/ijcmas.2017.606.183

\title{
Impact of Front Line Demonstrations on the Yield and Economics of Tomato in Bharatpur District of Eastern Rajasthan, India
}

\author{
Dilip Singh* \\ Sri Karan Narendra Agriculture University, Krishi Vigyan Kendra, Kumher, \\ Bharatpur (Rajasthan)-321001, India \\ *Corresponding author
}

\section{A B S T R A C T}

The Present study was carried out at Bharatpur district of Eastern Rajasthan during Kharif 2014.Front line demonstrations were conducted on tomato by the active participation of the farmers with the objective of improved technologies of tomato production potential. The improved technologies consist hybrid variety (Nunhems NP-1001), balanced fertilizers (soil test based) application and integrated pest and disease management, etc.

\section{Keywords}

Tomato, Front Line Demonstration, farmers practices, yield.

\section{Article Info}

Accepted:

21 May 2017

Available Online:

10 June 2017 Tomato is one of the most important vegetable crops of the country. The development of the Agriculture is primarily depends on the application of the scientific technologies by making the best use of available resources. One of the major constraints of traditional tomato farming is low productivity because of non-adoption of advanced technologies like improved varieties. To increase the production, productivity and quality of agricultural produce, front line demonstrations are being conducted at various farmers' field. All the recommended practices were provided to the selected farmers. The data related to the cost of cultivation, production, productivity, gross return and net return were collected as per schedule and analyzed. Result of the present study revealed that higher yield in the demonstrations was recorded $(451 \mathrm{q} / \mathrm{ha})$ as compared to farmers practice $(415 \mathrm{q} / \mathrm{ha})$ traditionally adopted by the farmers. The percentage increase in the yield over farmer's practice 8.67 was recorded. The extension gap, technology gap and technology index were computed $36 \mathrm{q} / \mathrm{ha}, 49 \mathrm{q} / \mathrm{ha}$ and $17 \%$ respectively. The demonstrated field gave higher net return Rs.165500 and B:C ratio 1:3.75. The result of the study indicated the gap existed in the potential yield and demonstration yield is due to soil fertility and weather conditions. Present results clearly show that the yield and economics of tomato can be boost up by adopting recommended technologies.

\section{Introduction}

Tomato (Lycopersicon esculentum Mill.) is an important vegetable crop grown almost throughout the world including tropical and temperate regions. It is cultivated both in the green houses on protective structures as well as under natural conditions. It ranks first among processed vegetables. It is consumed fresh in salad, fried in culinary preparations and processed in various forms viz. ketchup's auces, puree, paste, powder, juice soup and chutney etc. The fast foods such as pizza, burger, noodles etc. will not taste the same without addition of tomato sauces. Tomato is a rich source of vitamins $\mathrm{A}$ and $\mathrm{C}$ and is referred to as "poor man's orange". It adds variety of colours to the food. Tomato is a 
very good appetizer and its soup is said to be a good remedy for patients suffering from constipation. Lycopene that imparts red colour to ripe tomatoes is reported to possess anticancerous properties. It also serve as a natural anti-oxidant as the Beta-carotene functions to help prevent and neutralize free radical chain reaction and ascorbic acid is an effective scavenger of superoxide, hydrogen peroxide, singlet oxygen and other free radicals (Dhaliwal, 2014).

It is one of the most sensitive vegetable crops and fails miserably if growing conditions are too harsh. It is highly sensitive to frost. Dry and hot weather results in flower drops and poor fruit set. It can be grown in almost all states of India except in higher altitudes. Bihar, Karnataka, Uttar Pradesh, Orissa, Andhra Pradesh, Maharashtra, Madhya Pradesh, Punjab, Haryana and Assam are important tomato growing states in India.

In India during 2014-15 it was cultivated in 0.77 million hectare area with a production of 16.40 million tonnes. In Rajasthan its area and production were 16330 hectare and 110670 tonnes respectively. In Rajasthan the productivity of tomato was recorded $6.94 \mathrm{t} / \mathrm{ha}$, which was almost three time lower than the India's productivity i.e. 21.36t/ha (Anonymous, 2015). Average productivity of tomato crop is quite low and there exists a good scope to improve its average productivity in Rajasthan as well as in India to fulfil both domestic and national needs. The growth, yield and fruit quality of tomato are largely dependent on number of interacting factors. On the other hand tomato is a long duration crop with high yield which removes large quantities of nutrients from the soil. Like macronutrients, micronutrients are equally significant in plant nutrition. There is a need to go for balanced fertilization of both macro and micronutrients since micronutrients play a profound role in various metabolic functions of plant. Zinc is an essential component of a number of enzymes i.e. dehydrogenase, aldolase, isomerise, proteinase, peptidase and phosphohydrolase (Mousavi, 2011). It is directly involved in the synthesis of Indole Acetic Acid and proteins. The principal function is a metal activator of enzymes in plants. Zinc deficiency may be related to weather conditions, as it increases in cold and wet weather, which might be due to the limited root growth in cool soils, or reduced activity of microorganisms and release of zinc from organic material. Due to zinc deficiency leaves are small and distorted, the shoot length become shortened, giving the leaves a clustered arrangement near the growing tip. Its deficiency symptoms appear generally on younger leaves starting with interveinal chlorosis as well as an overall paleness of the whole plant. Flowers may drop off and fruit fail to set. Its deficiency occurs at soil pH above 7.5 and below 5.0. Nutrients can be applied either by conventional methods or by foliar application but the major advantage of foliar application is the instant availability of nutrients to plants.

A field trial was carried out at the four farmer's field at Bharatpur district of Rajasthan comes in Agro-climatic zone of Rajasthan III B Flood Prone Eastern Plane. Here, generally in winter's minimum temp., goes to $2-3^{\circ}$ and in summer maximum temp. Reaches to $47^{\circ} \mathrm{C}$, annual rainfall is $600-650$ $\mathrm{mm}$ per year. There is lot of scope of tomato growing in this area.

The main objective of Front line Demonstration (FLD) is to introduce suitable agriculture practices like high yielding varieties, seed treatment, spacing, timely sowing, nutrient management including micronutrients, growth hormones, pest and disease management etc. among the farmers accompanied with organizing extension programmes (field day) for horizontal 
dissemination of the technologies. FLD is playing a very important role for transfer of technologies and changing scientific treatment of the farmers by seeing and believing principle. In order to have better impact of the demonstrated technologies for farmers and field level extension functionaries, Front Line Demonstrations was conducted at farmer's field, in a systemic manner, to show case the high yielding new varieties, to convince them to about the potential of improved production technologies to enhance yield of tomato.

Generally, the agricultural technology is not accepted by the farmers as such in all respects. There is always gap between the recommended technology by the scientist and its modified form at the farmer's level which is major absentee in the efforts of increasing agricultural production in the country. It is need of the hour to reduce this technological gap between the agricultural technology recommended by the scientists or researchers and its acceptance by the farmers on their field. In view of the above facts, front-line demonstrations were undertaken in a systematic manner on farmer's field to show the worth of improved practices and convince the farmers to adopt in their farming system.

\section{Materials and Methods}

The present study was conducted in Bharatpur district of eastern Rajasthan during Kharif 2014. The genuine seeds of tomato cv. Nunhems NP-1001 were procured and distributed to four selected farmers. All the participating farmers were trained on various aspects of tomato production technologies. The field was prepared by deep ploughing and harrowing. The seeds were sown in well prepared raised bed during first week of July. All the recommended practices i.e. seed treatment by carbandazim 50 \% W.P. @ $2 \mathrm{~g} / \mathrm{kg}$ seed, transplanting of one month old seedlings, maintaining row spacing of $120 \mathrm{~cm}$ and $30 \mathrm{~cm}$ spacing with in rows. Recommended dose of manure and fertilizers (10 tonnes FYM, N:P:K 60:60:60 kg/ha. respectively) as basal application before transplanting and remaining $60 \mathrm{~kg}$ nitrogen by three split doses 30, 45 and 60 days after transplanting. Weed management, need based plant protection chemicals were used to manage the problem. The Zinc Sulphate, Boric Acid and Ferrous Sulphate @ 50mg each per liter of water at 45 and 75 days after transplanting were sprayed additionally over farmers practice (control).The yield and economic performance of front line demonstrations, the data on output were collected from FLDs as well as local plots from all selected farmers and finally the grain yield, cost of cultivation, net returns with the benefit cost ratio was worked out. An average of cost of cultivation, yield, net returns of different farmers was analyzed by the formula.

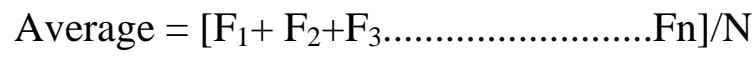

$\mathrm{F}_{1}=$ Farmer

$\mathrm{N}=$ No. of Farmers (6)

In the present study, technology index was operationally defined as the technical feasibility obtained due to implementation of Front line Demonstrations in tomato. To estimate the technology gap, extension gap and technology index following formula used by Samui et al., (2000), Sagar and Chandra 2004 have been used.

Technology Gap = Pi $($ Potential Yield $)-$ Di (Demonstration Yield)

Extension Gap $=$ Di $($ Demonstration Yield $)-$ Fi (Farmers yield)

Technology index - [(Potential Yield Demonstration yield/potential yield) $X$ 100]. 


\section{Results and Discussion}

\section{Performance of FLD}

A comparison of productivity levels between demonstration and farmers practice is shown in table 1. It is evident from results that under the demonstrated plots, performance of tomato (yield) was sustainable higher than in the local check. During the period of study, it was recorded that front line demonstrations tomato Hybrid variety Nunhems N.P.-1001 recorded the higher yield (451q/ha) than farmers practice $(415 \mathrm{q} / \mathrm{ha})$. The Percentage increase in the yield (8.67) over farmers practice was recorded. Similarly, yield enhancement in different crops in front line demonstrations were documented by Hiremath et al., (2007); Mishra et al., (2009); Kumar et al., (2010); Surywanshi and Prakash (1993) and Dhaka et al., (2010); Dhaka et al., (2015). From these results it is evident that the performance of the technology demonstrated was found to be better than the farmers practice under same environment conditions. The farmers were motivated by seeing the results in term of productivity and they are adopting the technologies. The yield of the front line demonstrations and potential yield of the crop was compared to estimate the yield gaps which were further categorized into technology index and Technology gap.

The technology gap shows the difference between potential yields over demonstration yield of the technology. The potential yield of the variety is $500 \mathrm{q} / \mathrm{ha}$. The Technology gap $49 \mathrm{q} /$ ha was recorded (Table 1). The front line demonstration was laid down under the supervision of Krishi Vigyan Kendra specialists at the farmer's field, there exist a gap between the potential yield and demonstration yield. This may be attributed to dissimilarities in soil fertility, salinity and to erratic rainfall and other vagaries of weather in the demonstration area. Hence, location specific recommendations may become necessary to narrow down the gap. These findings are similar to the finding of Sharma and Sharma (2004) in oil seeds at Baran District of Rajasthan.

Table.1 Yield, technology gap and technology index of demonstration

\begin{tabular}{|l|l|l|l|l|l|}
\hline Variables & Yield (q/ha) & $\begin{array}{l}\text { Increase (\%) over } \\
\text { farmers practice }\end{array}$ & $\begin{array}{l}\text { Technology } \\
\text { gap (q/ha) }\end{array}$ & $\begin{array}{l}\text { Extension } \\
\text { Gap (q/ha) }\end{array}$ & $\begin{array}{l}\text { Technology } \\
\text { Index (\%) }\end{array}$ \\
\hline Farmers Practice & 415 & - & - & - & - \\
\hline $\begin{array}{l}\text { Demonstration } \\
\text { Hybrid Nunhems NP- } \\
\text { 1001with full package of } \\
\text { practices }\end{array}$ & 451 & 8.67 & 49 & 36 & 17 \\
\hline
\end{tabular}

Table.2 Economics of front line demonstrations

\begin{tabular}{|l|l|l|l|l|l|}
\hline Variables & $\begin{array}{l}\text { Yield } \\
\text { q/ha. }\end{array}$ & $\begin{array}{l}\text { Cost of Cultivation } \\
\text { (Rs/ha.) }\end{array}$ & $\begin{array}{l}\text { Gross return } \\
\text { (Rs/ha.) }\end{array}$ & $\begin{array}{l}\text { Net return } \\
\text { (Rs/ha.) }\end{array}$ & Benefit:cost ratio \\
\hline Farmers practice & 415 & 56000 & 207500 & 151500 & $1: 3.71$ \\
\hline Demonstration & 451 & 60000 & 225500 & 165500 & $1: 3.75$ \\
\hline $\begin{array}{l}\text { Additional in } \\
\text { demonstration }\end{array}$ & 36 & 4000 & 18000 & 14000 & $3.50^{*}$ \\
\hline
\end{tabular}

*Incremental benefit: cost ratio. 
Comparative high Extension gap (36) (Table 1) emphasizes the need to educate the farmers and help them for optimizing the yield by adopting improved practices. Greater use of the latest improved production technologies applied to high yielding varieties can subsequently bridge this extension gap between demonstration yield and farmer's yield. New technologies, may, eventually lead farmers into discontinuing obsolete varieties.

Technology index shows the feasibility of the variety/technology at the farmer's field. The lower the value of technology index $(17 \%)$, more is the feasibility of the particular technology (Table 1). It means the technology is suitable for the Bharatpur district of Eastern Rajasthan. The results of the present study are in consonance with the finding and Hiremath and Nagaraju (2009) in onion, Dhaka et al., (2015) in coriander.

\section{Economics of frontline demonstrations}

Economics of tomato production under front line demonstrations was recorded and the results of the study have been presented in table 2. The results of economic analysis of tomato production revealed that front line demonstration recorded higher gross return (225500 Rs/ha) and net return, (165500 Rs.) With higher benefit cost ratio (1:3.75) as compared to farmers practice. These results are in accordance with findings of Hiremath et al., (2007), Dhaka et al., (2015) and Hiremath and Nagaraju (2009), further, additional cost of Rs 4000 per ha. In demonstration has increased additional net return Rs 14000 per ha. With incremental benefit cost ratio 3.50 suggesting it's higher profitability and economic viability of the demonstration. More and less similar results were also reported by Hiremath and Nagaraju (2009) and Dhaka et al., (2010). On the basis of above finding in present study, it is concluded that front line demonstrations of improved technology reduces technology gap to a considerable extent, thus leading to increased productivity of tomato in Bharatpur district of Rajasthan. This also improved linkages between farmers and scientists, and built confidence for adoption of the improved technology. Productivity enhancement under FLD's over farmers practices of tomato cultivation created a greater awareness, and motivated other farmers not growing tomato to adopt improved technologies in this crop i.e. tomato.

\section{References}

Anonymous. 2015. Indian Horticulture Database 2014.National Horticulture Board, Ministry of Agriculture, Government of India. Pp. 4.

Dhaka, B.L., Meena, B.S. and Suwalka, R.L. 2010. Popularization of Improved. Maize production technology through front line demonstrations in south eastern Rajasthan. J. Agri. Sci., 1(1): 39-42.

Dhaka, B.L., Poonia, M.K., Meena, B.S. and Bairwa, R.K. 2015. Yield and economic viability of coriander under front line demonstrations in Bundi district of Rajasthan. J. Hortl. Sci., 1092: 226-28.

Dhaliwal, M.S. 2014. Handbook of vegetables crops, Kalyani Publishers, Pp. 38-39.

Hiremath, S.M., Nagaraju, M.V. 2009. Evaluation of frontline demonstration on onion in Haveri district of Karnataka. Karnataka J. Agric. Sci., 22(5): 1092-1093.

Hiremath, S.M., Nagaraju, M.V. and Shasidhar, K.K. 2007. Impact of frontline demonstration on onion productivity in farmer's field. Paper Presented In: Nation Sem Appropriate Extn Strat manag Rural Resource, Univ. Agric. Sci., Dharwad, December 18-20, Pp. 100. 
Kumar, A., Kumar, R., Yadav, V.P.S. and Kumar, R. 2010. Impact assessment of frontline demonstrations of Bajara in Haryana state. Indian Re. J. Ext. Edu, 10(1): 105-108.

Mishra, D.K., Paliwal, D.K., Tailor, R.S. and Deshwal, A.K. 2009. Impact of front line demonstrations on yield enhancement of potato. Indian Res. J. Ext. Edu., 9(3): 26-28.

Mousavi, S.R. 2011. Zinc in crop production and interaction with phosphorus. Aust. J. Basic Appl. Sci., 5(9): 1503-1509.

Sagar, R.L. and Chandra, G. 2004. Evaluation of front line demonstrations on mustard in Sunderban, West Bengal. Indian J. Exten. Edu., 40: 96-97.
Samui, S.K. Maitra, S., Roy, D.K., Mondal, A.K. and Saha, D. 2000. Evaluation on front line demonstration on groundnut (Arachis hypogeal L). J. Indian Soc. Coastal Agric. Res., 18: 180- 183.

Sharma, R.N. and Sharma, K.C. 2004. Evaluation of Front Line Demonstration trials on oilseeds in Baran district of Rajasthan. Madhya J. Exten. Edu., 7: 72-75.

Suryawanshi, S.D. and Prakash, M. 1993. Impact of viable technology of promoting oil seeds in Maharastra. Indian J. Agri. Econ., 48: 420, p. 102106.

\section{How to cite this article:}

Dilip Singh. 2017. Impact of Front Line Demonstrations on the Yield and Economics of Tomato in Bharatpur District of Eastern Rajasthan. Int.J.Curr.Microbiol.App.Sci. 6(6): 15561561. doi: https://doi.org/10.20546/ijcmas.2017.606.183 